\title{
Production of Biofuel via Catalytic Hydrocracking of Kapuk (Ceiba pentandra) Seed Oil with NiMo/HZSM-5 Catalyst
}

\author{
I Gede Andy Andika Parahita ${ }^{1}$, Yustia Wulandari Mirzayanti ${ }^{1}$, Ignatius Gunardi ${ }^{1}$, Achmad Roesyadi ${ }^{1}$, and Danawati \\ Hari Prajitno ${ }^{1 *}$
}

${ }^{1}$ Department of Chemical Engineering, Industrial Technology Faculty, Sepuluh Nopember Institute of Technology, Surabaya, 60111, Indonesia

\begin{abstract}
Biofuel is one of alternative energy that is being developed today to solve the problem of limited fossil fuel as an energy source. The goal of this study is to produce biofuel from kapuk (Ceiba pentandra) seed oil (KSO) through catalytic hydrocracking process using NiMo/HZSM-5 catalyst. NiMo/HZSM-5 catalyst was obtained by impregnation of nickel and molybdenum as metallic precursors on HZSM-5 catalyst as support using incipient wetness impregnation method. It was found that the surface area of the catalyst was $222.1350 \mathrm{~m}^{2} / \mathrm{g}$, the pore diameter was $3.0148 \mathrm{~nm}$ and the pore volume was $0.1674 \mathrm{~cm}^{3} / \mathrm{g}$. The diffraction peaks of nickel oxide phase and the metallic phase of nickel were observed at $2 \theta$ of $62.5102^{\circ}$ and $51.7283^{\circ}$. Molybdenum oxide phases were observed at $2 \theta$ of $53.5674^{\circ}$ and $60.4682^{\circ}$. The catalytic hydrocracking process was performed using slurry pressure batch reactor at the temperature of $350^{\circ} \mathrm{C}$ for $2 \mathrm{~h}$. The obtained liquid product was analyzed using GC-MS in order to determine the organic content. It has been found that the highest compounds were the palmitic acid with 23.14 area\%. Besides, the hydrocarbon composition consisted of 33.93 area\% (i.e. 4.34 area\% cycloparaffins, 16.02 area $\%$ n-paraffins, 12.26 area $\%$ olefins, and 1.30 area $\%$ of aromatics) and 58.73 area\% of carboxylic acid. Thus, it can be concluded that NiMo/HZSM-5 catalyst can convert $\mathrm{KSO}$ into biofuel through catalytic hydrocracking process at the temperature of $350^{\circ} \mathrm{C}$ for $2 \mathrm{~h}$.
\end{abstract}

\section{Introduction}

Biofuel production as renewable energy is promising alternatives to substitute fossil fuel from the depletion of world oil reserve [1]. Biofuel is referred to enrichedenergy chemicals derived from such plants, microalgae, and bacteria that used to fulfill the global energy demand. However, approximately $95 \%$ of the biofuels produced today are derived from edible vegetable oils. It caused an ongoing debate regarding the use of agricultural lands for fuel purposes. This resulting the exploration of biofuel production from inedible vegetable oil such as kapuk (Ceiba pentandra) seed oil (KSO).

Kapuk (Ceiba pentandra) is a tropical tree belongs to Malvales order and Malvaceae family. It was originally coming from Southeast Asia and grown naturally through tropical region [2]. KSO has the capability as a sustainable biodiesel feedstock because of simple cultivation and short harvest time (4-5

*Corresponding author: dana@chem-eng.its.ac.id months) [3]. KSO contains a unique fatty acid (malvalic acid) which are more reactive than the double bond carbon (polyunsaturated) in reaction by atmospheric oxygen. The hydrocarbon chain has the ability to reduce oxidation stability of bio-oil [4].

Biofuel consists of hydrocarbon developed by many technologies such as hydrodeoxygenation, thermal pyrolysis, and transesterification [5]. Two main routes to converting vegetable oil into hydrocarbon were catalytic cracking using zeolites and hydrodeoxygenation using metals or metal-sulfidesbased catalyst [6]. Many study had applied cracking vegetable oil using HZSM-5 zeolite to produce hydrocarbons because of its large surface area, crystallinity, and high acidity [7]. HZSM-5 zeolite has acidic site favoring hydrogen transfer that able to produce high aromatic content and some polyaromatic [8] In another study, the renewable diesel produced through hydroprocessing using $\mathrm{NiMo/titania}$ catalyst has a high cetane number when it was compared to conventional diesel and hence has better combustion 
characteristics [9]. But it still contains high oxygen content.

Nowadays, the production of biofuel with inedible vegetable oil raw material has been developed through catalytic hydrocracking process to reduce the oxygen content in the long chain of trigliserides. Hydrocracking may be preferred conversion route of vegetable oil into biofuel using hydrogen to selectivity remove the oxygen atoms [10]. The selective catalyst in catalytic hydrocracking process was very important to obtain the appropriate conversion. $\mathrm{Ni}$ and Mo transitions metals used as active compounds and promoters to enhance the active site on the H-ZSM-5 catalyst used. Ni catalyst can promote the dehydrogenation, hydrogenation and hydrocracking reaction. Ni also can be used in more aggressive role of aromatic hydrocracking process because of its good hydrogenating properties [11]. Chen et al reported that when Ni/HZSM-5 used in catalytic hydroprocessing of FAMEs, the n-paraffin $\left(\mathrm{C}_{17}-\mathrm{C}_{18}\right)$ and isoparaffin $\left(\mathrm{C}_{5^{-}}\right.$ $\mathrm{C}_{16}$ ) compounds were increased as long as the increase of temperature. [12] In another case Mo catalyst can promote the hydrodeoxygenation reaction [13]. The impregnation of Mo into HZSM-5 can promote the cyclization reaction and aromatization reaction in cracking of vegetable oil process [8]. In another study, the NiMo catalyst selectivity for renewable diesel source $\left(\mathrm{C}_{15}-\mathrm{C}_{18}\right.$ range hydrocarbon) using temperature at $320^{\circ} \mathrm{C}$ for $1 \mathrm{~h}$ reached $91 \%$. The yield of paraffin $\mathrm{C}_{15}$ $-\mathrm{C}_{18}$ range hydrocarbon increased due to the cracking of heavier molecules of triglycerides into diesel range hydrocarbon as the increasing of temperature from 320 to $400^{\circ} \mathrm{C}$ but it slightly decreased at $420^{\circ} \mathrm{C}$ due to the cracking of $\mathrm{C}_{18}$ and other triglyceride molecules into smaller molecules [9]. Thus, it is interesting to produce biofuel $\left(\mathrm{C}_{15}-\mathrm{C}_{18}\right.$ range hydrocarbons) from kapuk (Ceiba pentandra) seed oil through catalytic hydrocracking process at average temperature reaction of $350^{\circ} \mathrm{C}$.

\section{Material and methods}

\subsection{Materials}

Kapuk seed oil (KSO) was provided from Pandaan, East Java, Indonesia as reported in previous study [14]. The commercial ammonium-ZSM-5 zeolite powder was purchased from Zeolyst International $\left(\mathrm{SiO}_{2} / \mathrm{Al}_{2} \mathrm{O}_{3}\right.$ Mole Ratio $=80$ ). Nickel (II) nitrate hexahydrate and ammonium heptamolybdate tetrahydrate with $98 \%$ purity was purchased from Merck.

\subsection{Catalyst Preparation}

As the previous study, the HZSM-5 catalyst was prepared by calcined ammonium-ZSM- 5 at $550^{\circ} \mathrm{C}$ for $5 \mathrm{~h}$ under at air atmosphere [14]. NiMo/HZSM-5 was prepared by incipient wetness impregnation method using $1.1247 \mathrm{M}$ of nickel nitrate and $1.3761 \mathrm{M}$ of ammonium heptamolybdatetetrahydrate. It was dissolved in the volume of the solution according to the total pore volume of the HZSM-5 support (0.2712 $\mathrm{cm}^{3} / \mathrm{gram}$ ) [13]. The solution was pouring into HZSM5 and stirred for $3 \mathrm{~h}$ to obtained homogenous metal impregnated catalyst. Then, the catalyst dried under the temperature at $120^{\circ} \mathrm{C}$ for $12 \mathrm{~h}$ and calcined at $400^{\circ} \mathrm{C}$ with air flow for $5 \mathrm{~h}$. At last, the catalyst reduced with hydrogen flow at $450^{\circ} \mathrm{C}$ for $2 \mathrm{~h}$ to obtain activated site catalyst.

\subsection{Catalyst Characterization}

The pore volume, specific surface area, and average pore diameter were obtained by an automatic specific surface area measurement (Quantachrome Instruments version 10.01) with the $\mathrm{N}_{2}$ adsorption-desorption isotherm at $77 \mathrm{~K}$. The total pore volume, specific surface area, and average pore diameter were calculated using the Brunauer-Emmet-Teller (BET) method. The phase analysis of the catalyst was obtained using an X-ray diffractometer (Philips X'PERT MPD) at $30 \mathrm{~mA}$ and $40 \mathrm{kV}$ with $\mathrm{K} \alpha$ radiation. Morphology catalyst, actual metal content, and dispersion were performed by scanning electron microscopy-energy dispersive X-ray (SEM-EDX) at 20 $\mathrm{kV}$.

\subsection{Catalytic hydrocracking}

Catalytic hydrocracking of KSO was performed in a slurry pressurized batch reactor system equipped with a mechanical stirrer (Parr USA 4563) as reported by the previous study [14]. About $200 \mathrm{~mL}$ of KSO and the catalyst approximately $0.56 \mathrm{wt} \%$ to $\mathrm{KSO}$ were loaded into the reactor. Furthermore, the reactor was purged with nitrogen to remove dissolved air in the oil. The operating condition of the experiment carried out at a temperature $350^{\circ} \mathrm{C}$ for $2 \mathrm{~h}$ with reactor pressure range of 10-15 bar after hydrogen flow for $1 \mathrm{~h}$. The obtained liquid product was characterized using gas chromatography-mass spectrophotometry (GC-MS).

\section{Results and discussion}

\subsection{Catalyst characterization}

Fig. 1. showed the XRD patterns of NiMo/HZSM-5 catalyst. As reported by the previous study [14], the main peaks of HZSM-5 zeolite observed at $2 \theta$ of $7.87^{\circ}$, $8.74^{\circ}, 23.04^{\circ}, 23.24^{\circ}, 23.64^{\circ}, 212.26^{\circ}$ and $24.31^{\circ}$ indicate that HZSM-5 have a framework type MFI. Besides, after the impregnation process of nickel and molybdenum into the HZSM-5, the structure of NiMo/HZSM-5 catalyst still similar to HZSM-5. It indicates that metals impregnation did not change the main structure of HZSM-5 [15]. The diffraction peaks intensity of NiMo/HZSM-5 catalyst showed that the nickel metallic phase was formed at $2 \theta$ of $51.7283^{\circ}$, nickel oxide phase was formed at $2 \theta$ of $62.5102^{\circ}$, whereas for molybdenum oxide phase for peaks intensity were formed at $2 \theta$ of $53.5674^{\circ}$ and $60.4682^{\circ}$. 
The actual metal content of NiMo/HZSM-5 was observed by EDAX analysis as showed in Fig.2. It

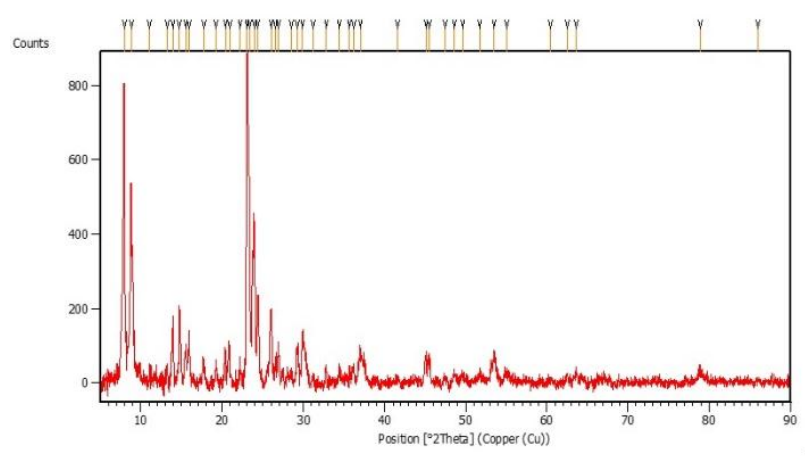

Fig. 1. XRD pattern of NiMo/HZSM-5 catalyst

The SEM image of NiMo/HZSM-5 in Fig. 2. showed that $\mathrm{Ni}$ and Mo metals are homogeneously dispersed over the microporous HZSM-5 support. Table 1 shows the textural properties of HZSM-5 and NiMo/HZSM-5 catalyst from BET analysis.

Table 1. The catalyst properties

\begin{tabular}{|c|c|c|c|}
\hline Catalyst & $\begin{array}{c}\text { BET } \\
\text { surface } \\
\text { area, } \\
\left(\mathrm{m}^{2} / \mathrm{g}\right)\end{array}$ & $\begin{array}{c}\text { Average } \\
\text { pore } \\
\text { diameter, } \\
(\mathrm{nm})\end{array}$ & $\begin{array}{c}\text { Total pore } \\
\text { volume, } \\
\left(\mathrm{cm}^{3} / \mathrm{gram}\right)\end{array}$ \\
\hline HZSM-5 & 375.121 & 2.4900 & 0.2712 \\
\hline NiMo/HZSM-5 & 222.135 & 3.0148 & 0.1674 \\
\hline
\end{tabular}

showed that the $\mathrm{Ni}$ and Mo loading were approximately $0.26 \%$ wt and $0.93 \%$ wt.

The total surface area of NiMo/HZSM-5 is 255.653 $\mathrm{m}^{2} / \mathrm{g}$, which is lower than the total surface area of HZSM-5 $\left(375.121 \mathrm{~m}^{2} / \mathrm{g}\right)$. It seems that the metal content blocking some micropores, clogging the external mesopores and decreasing the total area of the parent zeolitic support [16]

\subsection{Product analysis}

The obtained liquid product compounds were shown in Fig. 3. The most abundant compound in the liquid product produced by KSO catalytic hydrocracking process using NiMo/HZSM-5 catalyst at $350^{\circ} \mathrm{C}$ was the palmitic acid with 23.14 area\%. The formation of carboxylic acid in the liquid product shows that triglyceride contained in KSO is cracked into the form of free fatty acids. Free fatty acids that form trough hydrogenation reaction in hydrocracking process that cracked the triglycerides bond [14]. The hydrocarbon compounds observed of 33.93 area\% (i.e. 4.34 area $\%$ cycloparaffins, 16.02 area $\%$ n-paraffins, 12.26 area $\%$ olefins, and 1.30 area $\%$ of aromatics). The aromatic content that found in the liquid product such as pentylbenzene of 1.22 area $\%$ was affected by the presence of polyunsaturated fatty acid in the raw KSO. Furthermore, the presence of olefin of 12.26 area $\%$ indicates that the hydrogenation reaction occurring in the hydrocracking process was followed by cyclization process.

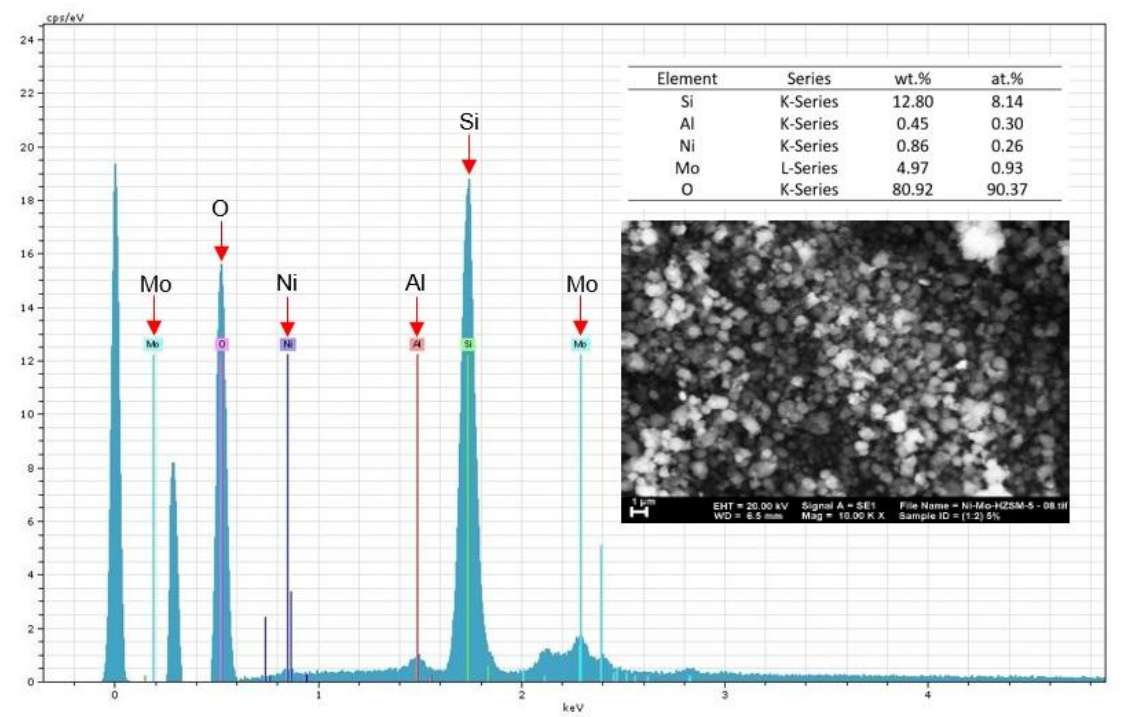

Fig. 2. SEM image and EDX pattern of NiMo/HZSM-5 catalyst 


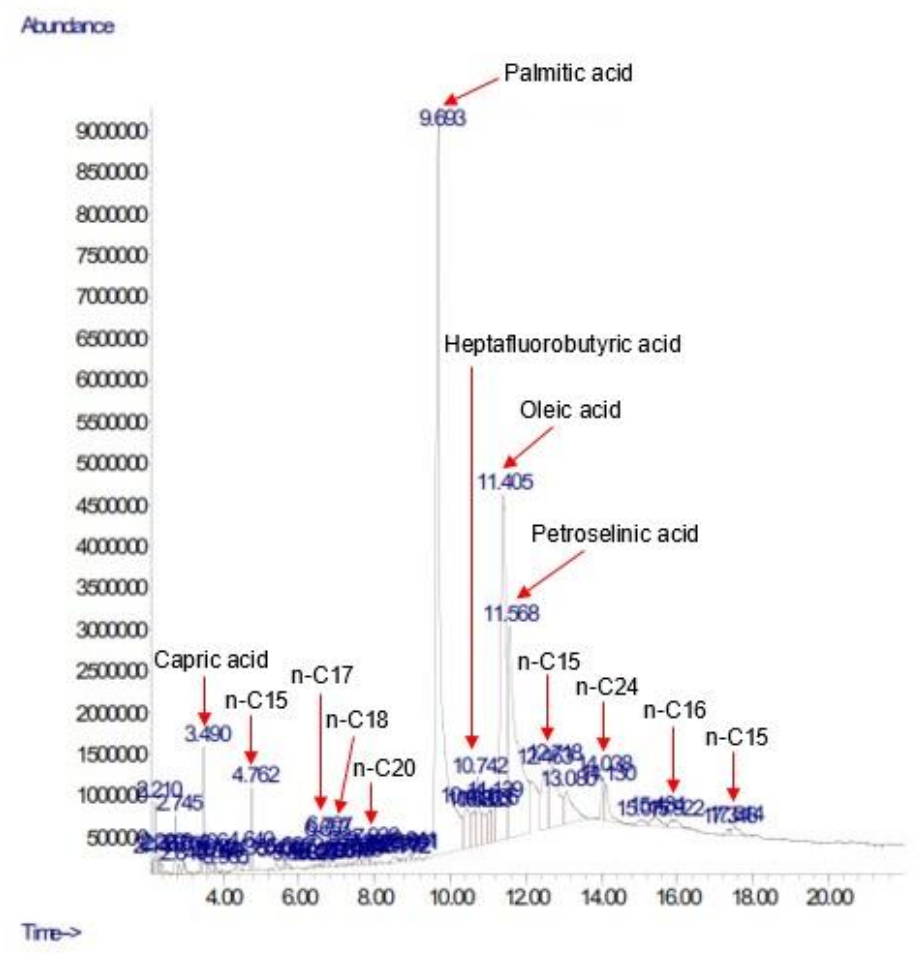

Fig. 3. GC-MS spectra of hydrocarbon liquid product using NiMo/HZSM-5 catalyst at $350^{\circ} \mathrm{C}$

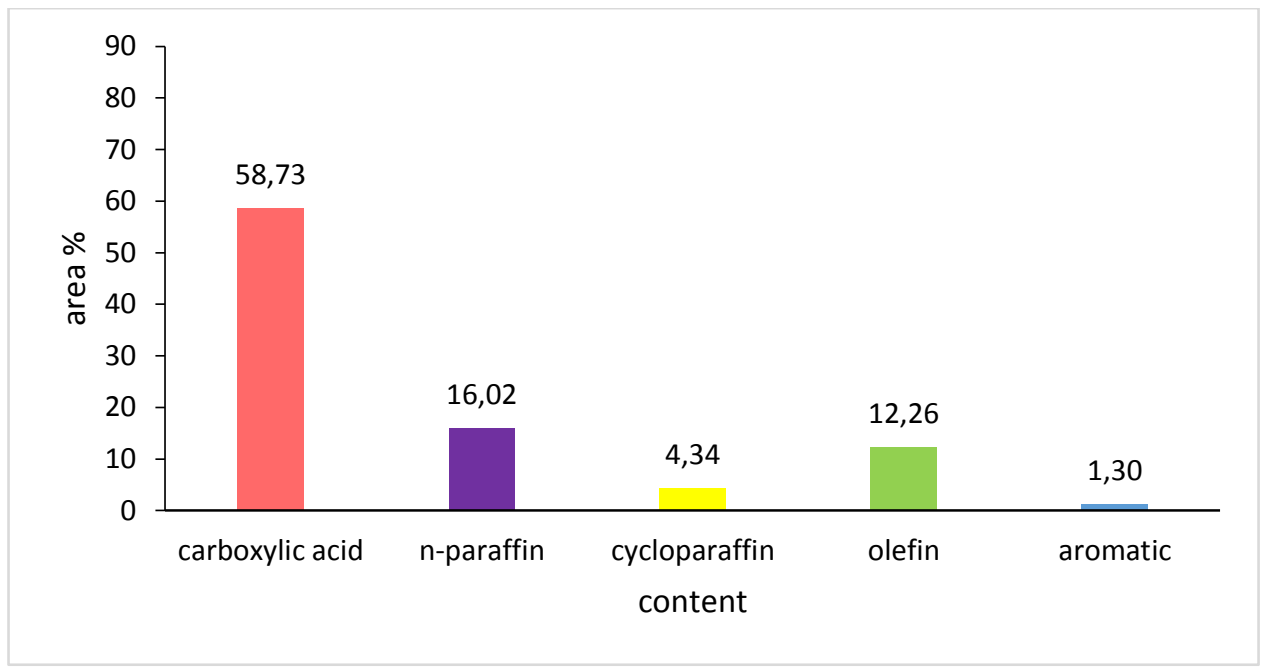

Fig. 4. The compounds of obtained hydrocarbon liquid product produced using NiMo/HZSM-5 catalyst at $350^{\circ} \mathrm{C}$

Fig. 4 showed carboxylic acid is quite abundant that was equal to 58.73 area $\%$ consisting mostly of palmitic acid proves that triglyceride in raw KSO has begun cracked through the catalytic hydrocracking process into saturated fatty acids. This indicates that the unsaturated fatty acids present in the raw material have begun to crack into saturated fatty acids. The contribution of $\mathrm{Ni}$ metal in the cracking process transforms the unsaturated carboxylic acid compounds into saturated carboxylic acid through hydrogenation reaction. The presence of $\mathrm{Ni}$ can reduce the barrier of
$\mathrm{C}=\mathrm{O}$ bonds [17]. After the saturated fatty acid is formed, the subsequent reaction is the decarbonylation reaction, but at this stage the decarbonylation reaction has not occurred maximally because the cracking activity has required higher reaction temperature because temperture increase will increasing the conversion $[18,19]$. Furthermore, hydrocarbon compounds such as olefin (12.26area\%), n-paraffin (16.02 area\%), cycloparaffin (4.34 area\%) and aromatics $(1.30$ area $\%)$ are formed indicating that the successful breaking of double bonds in the long chain 
fatty acids, although still in small amounts. The olefin compound formed is obtained by the dehydrogenation reaction of n-paraffin [20]. Table 2. showed that the most abundant biofuel fraction was gasoil-range alkanes $\left(\mathrm{C}_{15}-\mathrm{C}_{18}\right)$ with 9.96 area\%. Furthermore, another fraction was kerosene-range alkanes $\left(\mathrm{C}_{10}-\mathrm{C}_{14}\right)$ with 5.09 area\%. Temperature above $350^{\circ} \mathrm{C}$ needed to crack more free fatty acid into biofuel fraction.

Table 2. Various hydrocarbon contents of liquid product over NiMo/HZSM-5 catalyst

\begin{tabular}{lcccc}
\hline \multicolumn{4}{c}{ Various hydrocarbon contents of liquid product (area\%) } \\
\hline $\mathrm{nC}_{5}-\mathrm{nC}_{9} \quad \mathrm{nC}_{10}-\mathrm{nC}_{14}{ }^{\mathrm{a}}$ & $\mathrm{nC}_{15}-\mathrm{nC}_{18}{ }^{\mathrm{b}}$ & $\mathrm{nC}>18$ & $\begin{array}{c}\text { Cycloparaffin, } \\
\text { olefin, and } \\
\text { aromatic }\end{array}$ \\
\hline 0 & 5.09 & 9.96 & 0.00 & 16.90 \\
\hline $\begin{array}{l}{ }^{a} \text { kerosene range alkanes } \\
{ }^{b} \text { gasoil range alkanes }\end{array}$ & & &
\end{tabular}

\section{Conclusion}

Catalytic hydrocracking of kapuk (Ceiba pentandra) seed oil (KSO) with NiMo/HZSM-5 catalyst can be applied to biofuel production. The NiMo/HZSM-5 catalyst surface area was $222.1350 \mathrm{~m}^{2} / \mathrm{g}$, the pore diameter was $3.0148 \mathrm{~nm}$ and the pore volume was $0.1674 \mathrm{~cm}^{3} / \mathrm{g}$. the biofuel contained hydrocarbon composition consisted of 16.64 area\% (i.e. 4.34 area $\%$ of cycloparaffins, 16.02 area\% of n-paraffins, 12.26 area\% of olefins, and 1.30 area\% of aromatics) and 58.73 area\% of carboxylic acids. The higher temperature needed to convert more carboxylic acids into hydrocarbons fraction.

\section{References}

1. S. Dharma, H. C. Ong, H. H. Masjuki, A. H. Sebayang, A. S. Silitonga, Energ. Convrs. Manag. 128 66-81 (2016)

2. A. S. Silitonga, H. C. Ong, T. M. I. Mahlia, H. H. Masjuki, W. T. Chong, Fuel. 108 855-858 (2013)

3. M. Yuniwati, Tek. Tech. Sci. 202-212 (2012)

4. X.H. Yu, R. Rawat, J. Shanklin, BMC. Plant. Bio. 11 1471-1481 (2011)

5. Z-X. Xu, P. Liu, G-S Xu, Q. Liu, Z-X. He, Q. Wang, Energ. 133 666-675 (2017)

6. J. Horacek, D. Kubicka, Fuel. 198 49-57 (2017)

7. D. P. Botas, A. Garcia, J. de Vicente, R. Ramos, Catal. Today. 195 59-70 (2012)

8. R. Frety, J. G. A. Pacheco, M. R. Santos, J. F. Padilha, A. F. Azevedo, S. T. Brandao, L. A. M. Pontes, Anal. App. Pyro. 109 56-64 (2014)

9. R. Kumar, S. A. Farooqui, M. Anand, R. Kumar, R. Joshi, A. Khan, A. K. Sinha, Catal. Com. 98 102-106 (2017)

10. J. K. Satyarthi, D. Srinivas, Energ. Fuel. 25 3318-3322 (2011)

11. L. Chen, H. Li. J. Fu, C. Miao, Lv. Pengmei, Z. Yuan, Catal. Today. 259 266-276 (2016)

12. H. Morelo, C. Galarrga, F. Feng, E. Hernandez, V. Birss, P. Pereira, Catal. Lett. 132 402-209 (2009)
13. M. F. Ali, B. M. El Ali, J. G. Speight, Handbook of Industrial Chemistry, Mc GrawHill (2005)

14. Y. W. Mirzayanti, A. Roesyadi, D. H. Prajitno, $7^{\text {th }}$ Annual Basic Science International Conference (2017)

15. S. Wang, Q. Yin, J. Guo, B. Ru, L. Zhul, Fuel. 108 597-603 (2013)

16. G. Vitale, H. Morelo, E. Hernandez, S. Aquino, V. Birss, P. Pereira-Almao, App. Catal. 452 7587 (2013)

17. C. Dupont, R. Lemeur, A. Daudin, P. Raybaud, Catal. 279 276-286 (2011)

18. H. Zhang, H. Lin, Y. Zheng, App. Catal. B. 160-161 415-422 (2014)

19. J. Liu, K. Fan, W. Tian, C. Liu, L. Rong, Hydro. Energ. 37 17731-17737 (2012)

20. S. K. Kim, S. Brand, H. Lee, Y. Kim, J. Kim, Chem. Eng. 288 114-123 (2013) 